\title{
Identification of Differentially Expressed Genes During Pseudomonas fluorescens Mediated Systemic Resistance in Cabbage
}

\author{
Kaunain Roohie, Sharanaiah Umesha* \\ Department of Studies in Biotechnology, University of Mysore, Manasagangotri, Mysore, Karnataka, India
}

Email address:

umeshgroup@yahoo.co.in (S. Umesha),su@appbot.uni-mysore.ac.in (S. Umesha), rooh.raheem@gmail.com (K. Roohie)

To cite this article:

Kaunain Roohie, Sharanaiah Umesha. Identification of Differentially Expressed Genes During Pseudomonas fluorescens Mediated Systemic Resistance in Cabbage. Plant. Vol. 3, No. 4, 2015, pp. 30-36. doi: 10.11648/j.plant.20150304.11

\begin{abstract}
The study of microbial ecology and the microbial interactions with plants provides an insight into the biocontrol of plant diseases using antagonistic microbes. Pseudomonas fluorescens was used as a biological control agent against black rot disease caused by Xanthomonas campestris pv. campestris. The Suppression subtractive hybridization (SSH) was used to elucidate the differentially expressed genes in cabbage (Brassica oleracea var. capitata) upon the application of Pseudomonas fluorescens. A total of 140 expressed sequence tags (EST) were obtained. The analyses of these ESTs showed that many defense related genes like peroxidase, heat shock proteins, were upregulated. Many transcripts related to signalling pathways and pathogen recognition were identified. The important finding of the study is the identification of the unigene belonging to the SWEET protein family in cabbage. The study also resulted in the identification of 10 unigenes which possibly depict the interaction of Pseudomonas fluorescens in combating disease. These unigenes have been submitted to dbEST. The results show that those genes which are upregulated during pathogen attack are also induced upon application of Pseudomonas fluorescens indicating the possible mechanism of systemic resistance induced by $P$. fluorescens to combat disease.
\end{abstract}

Keywords: Xanthomonas campestris pv. campestris, RT-PCR, Pseudomonas Fluorescens,

Suppression Subtractive Hybridization

\section{Introduction}

Cabbage (Brassica oleracea var. capitata) Pammel Dowson is an important vegetable grown worldwide. Black rot of cabbage has been a disease of global importance (Williams 1980). Xanthomonas campestris pv. campestris the causative agent of black rot disease, commonly enters the cabbage leaf through the hydathodes, and under favorable conditions spreads systemically in the xylem vessels throughout the plant. The intercostal's regions become chlorotic, and desiccated after they become surrounded by blackened veins (Sutton and Williams 1970). Biological control of plant diseases makes management of plant diseases less dependent on the use of high-risk chemicals, and it is environmentally friendly. Fluorescent pseudomonads, non-pathogenic rhizobacteria, are among the most effective biological control agents against soilborne plant pathogens (Mishra and Arora 2012). Pseudomonas fluorescens is one of the most important biocontrol agents against certain seed and soil-borne plant pathogens. Several isolates of Pseudomonas fluorescens, $P$. putida, and $P$. aureofaciens suppress the soil-borne pathogens through rhizosphere colonization, antibiosis and iron chelation by siderophore production (Mishra and Arora 2012). Fluorescent pseudomonads promote plant growth by production of plant growth-promoting substances and thus are called plant growth promoting rhizobacteria (PGPR). PGPR are known to cause resistance against fungal, bacterial and viral diseases (Kurkcuoglu et al. 2007; Vanitha et al. 2009). Plant growth-promotion and activation of defense genes by PGPR application is an important strategy in plant protection. The potential of $P$. fluorescens in providing disease resistance and plant growth promotion has been proved in a variety of crops and pathogen interaction, as in sheath blight, sheath rot, blast of rice and bacterial blight of cotton (Nandakumar et al. 2001); 
groundnut (Meena et al. 2000) and wilt disease of tomato (Ramamoorty et al. 2002). The induction of systemic resistance by the Pseudomonas strains was demonstrated in bean, carnation, rice, and cucumber (Alstrom 1991; Nandakumar et al. 2001). The strains of Pseudomonas spp. were found to cause resistance against various pathogens in cucumber (Wei et al. 1991) and radish (Hoffland et al. 1996). The use of $P$. fluorescens and its effect has been studied at the rhizosphere level, but very little is known about its effect in the phyllosphere of the host plant. In general, the phyllosphere of plants is a biocoenosis of different non-pathogenic micro-organisms, such as bacteria and fungi including yeasts, that colonize the host plant without causing significant morphological changes in the appearance of the plant. Positive results were achieved with $P$. fluorescens, which controlled bacterial wilt and also bacterial blight on potato in both field and laboratory trials (Beattie and Lindow 1995; Burr et al. 1996). A study by Singh et al. (2004) showed that the non-pathogenic bacterium Pseudomonas fluorescens Bk3 can suppress the conidial germination and the in vitro the mycelium growth of the pathogen Venturia inaequalis (Singh et al. 2004). The black rot of cabbage caused by Xanthomonas campestris pv. campestris is difficult to manage. Black rot management includes the use of pathogen-free seed and transplants along with the use of resistant varieties, cultural practices and physical and chemical treatment. But in recent years the control of black rot in brassicas has been experimentally demonstrated with antagonistic bacteria (Massomo et al. 2004). Pseudomonas and Bacillus species are known to produce a variety of antimicrobial substances, and these may be involved in disease suppression (Schmidt et al. 2001). The potentiality of rhizobacteria in management of black rot was studied by using the Pseudomonas fluorescens KA19 strain isolated from soil and the secondary metabolites produced by them which control the disease development (Mishra and Arora 2012).

The present study describes the possible machinery of the host- Brassica oleracea var. capitata - P. fluorescens interaction. In order to accomplish the task both black rot resistant and susceptible cultivars of cabbage were selected, and gene expression studies were conducted upon challenge inoculation with black rot pathogen. Suppression subtractive hybridization was performed to target the differentially expressed genes before and after application of $P$. fluorescens upon challenge inoculation with Xanthomonas campestris pv. campestris.

\section{Materials and Methods}

\subsection{Isolation of P. Fluorescens from Soil}

The strains of $P$. fluorescens were isolated from native soil where cabbage were grown. The bacteria were isolated by adding approximately $1 \mathrm{~g}$ of soil to $9 \mathrm{~cm}^{3}$ of sterile distilled water. The solution was vortexed, allowed to settle for at least $20 \mathrm{~min}$, and then vortexed again. The bacterial fraction was collected from the supernatant following centrifugation at $8000 \mathrm{~g}$ and aliquots were plated onto King's B medium (King et al. 1956). The isolated $P$. fluorescens strains were further evaluated for their antagonistic activity by the dual culture technique. The identity of the isolate based on inhibition zone with the best antagonistic activity was confirmed by performing various tests specific to $P$. fluorescens. The isolate which showed very high inhibition zone was chosen for further studies (UOMPfu-5). The 48 h-old-cultures grown on King's medium B broth was centrifuged at $8000 \mathrm{~g}$ for $10 \mathrm{~min}$. Inoculum was prepared by adjusting the bacterial concentration with sterile distilled water to $1 \times 10^{8} \mathrm{cfu} \mathrm{cm}^{-3}$ (Vanitha et al. 2009).

\subsection{Plant Material}

The black rot susceptible and resistant cultivars were chosen for the study based on our previous experiments. The seeds of black rot susceptible cultivar Golden acre and resistant cultivar Pusa mukta were sown in earthern pots $(9 \mathrm{~cm}$ dia) and seedlings were maintained under $80 \%$ relative humidity at $25^{\circ} \mathrm{C}$ and under 16 hour light $/ 8$ hour dark period before being inoculated with $P$. fluorescens (UOMPfu-5). Leaves were collected at 48 hours post inoculation (hpi). The leaves were immediately frozen in liquid nitrogen and stored at $-80{ }^{\circ} \mathrm{C}$ until RNA extraction.

\subsection{Inoculation Studies}

The seeds of the susceptible cultivar Golden acre were used in the present investigation. The $48 \mathrm{~h}$ old culture of $P$. fluorescens grown on King's medium B broth was centrifuged at $8000 \mathrm{~g}$ for $10 \mathrm{~min}$ using bench top centrifuge. Inoculum was prepared by adjusting the bacterial concentration with sterile distilled water to $1 \times 10^{8} \mathrm{cfu} \mathrm{cm}^{-3}$ (Vanitha et al. 2009). The seeds were then pretreated with $P$. fluorescens (UOMPfu-5) by placing the seeds in a $100 \mathrm{ml}$ solution containing $20 \mu \mathrm{l}$ Tween 20 and the $1 \mathrm{ml}$ of $P$. fluorescens (UOMPfu-5) inoculum for $5 \mathrm{~h}$ on a rotary shaker at $37^{\circ} \mathrm{C}$ and then the seeds were air dried and used for further experiments. The four week old seedlings were kept under $80 \%$ relative humidity, at $25^{\circ} \mathrm{C}$ and under 16 hour light $/ 8$ hour dark period before being inoculated with Xanthomonas campestris pv. campestris (UOMBT-6 isolate). The inoculum was prepared by growing the bacteria in nutrient broth incubated at $28 \pm 2^{\circ} \mathrm{C}$ for $36 \mathrm{~h}$ on a rotary shaker at $100 \mathrm{rpm}$. The final inoculum was prepared by adjusting the bacterial concentration with sterile distilled water to $1 \times 10^{8} \mathrm{CFU} \mathrm{ml} \mathrm{m}^{-1}$ at $\mathrm{A} 610 \mathrm{~nm}$ using a UV-visible spectrophotometer (Hitachi U-2000, Tokyo, Japan). Fourweek-old seedlings were inoculated by spraying the bacterial suspension. Plants were sampled 10 days after inoculation with the pathogen. Leaves were collected 48 hours post inoculation (hpi) inoculation. The leaves were immediately frozen in liquid nitrogen and stored at $-80{ }^{\circ} \mathrm{C}$ until RNA extraction. 


\subsection{RNA Isolation}

Total RNA was isolated from the cabbage leaves harvested $48 \mathrm{~h}$ post inoculation (hpi) using the RNeasy Plant kit (Qiagen, France). RNA yield was determined by measuring the absorbance at $260 \mathrm{~nm}$ and RNA integrity was checked by electrophoresing $3 \mu \mathrm{g}$ of total RNA through 1.2\% agarose gel. Poly (A)+ RNA was purified from total RNA using mRNA purification kit (Bangalore Genei, Bangalore, India).

\subsection{Suppression Subtractive Hybridization Studies}

\subsection{1. cDNA Library Construction and Amplification of cDNA Inserts}

Suppression subtractive hybridization was performed as described by Diatchenko et al. (1996) using PCR select cDNA subtraction kit (BD biosciences Clonetech, Palo Alto, CA, USA) according to the manufacturer's instructions. The cDNA obtained from the susceptible cultivar Golden acre after the application of $P$. fluorescens 48 hpi was used as "tester" population and cDNA from the mock inoculated Golden acre cultivar was used as "driver" population. The efficiency of subtraction was analyzed by comparing cDNA abundance before and after subtraction by PCR using specific primers for the constitutively expressed cabbage specific 18S rRNA gene (Table 1). PCR amplification was performed using Taq DNA polymerase (Bangalore Genei, Bangalore, India) and $5 \mu 1$ aliquots were removed following determined numbers of PCR cycles. The amplified products were examined in $2 \%$ agarose gel. The differences in the number of cycles, which were needed to generate an approximately equal amount of the corresponding PCR product in subtracted and unsubtracted samples, served to indicate the subtraction efficiency.

\subsubsection{Cloning of the Subtracted cDNA}

The secondary PCR products were purified using the QIAquick PCR purification kit (Qiagen, France). The subtracted cDNA fragments were cloned into the pGEMTeasy using a pGEMT -easy cloning kit (Promega, USA) and transformed into Escherichia coli JM109 cells. Individual colonies containing recombinant plasmids were inoculated into $100 \mu \mathrm{l}$ Luria Bertani broth in 96 well microtitre plates. Cultures were grown overnight at $37^{\circ} \mathrm{C}$ with gentle shaking $(100 \mathrm{rpm}) .100 \mu \mathrm{l}$ of $15 \%$ glycerol was added to each of the wells and the microtitre plates were stored at $-80^{\circ} \mathrm{C}$ until use.

\subsubsection{Identification of Insert Size of $c D N A$ by PCR Amplification}

Sequencing of cDNA clones was performed using M13 primer. In order to correct the sequencing ambiguities, the sequences were edited by removing the plasmid and SSH adaptor sequences. The edited sequences were used to query the NCBI (National centre for Biotechnology Information, USA) databases using the blastX, blastN and dbEST algorithms. The cDNA were classified according to the E-values generated in the searches. Sequences were checked for stop codons to ensure that cDNA fragments represented a position of open reading frame.

\subsection{Enzyme Assay}

\subsubsection{Preparations of Crude Enzyme Extract}

The cabbage seeds of the susceptible cv. Golden acre were treated with $P$. fluorescens and subjected to seed germination (ISTA, 2014). The four week old seedlings were challenge inoculated with $X$. campestris pv. campestris. The seedlings were harvested at different time intervals of 6, 12, 24, 48 and 72 hpi respectively. One gram of cabbage seedlings was macerated to a fine paste in a pre-chilled mortar with $50 \mathrm{mM}$ buffer $(\mathrm{pH} 8.8)(\mathrm{w} / \mathrm{v} ; 1: 1)$. One gram of cabbage seedlings was homogenized in $10 \mathrm{mM}$ phosphate buffer $(\mathrm{pH} \mathrm{6.0)}$ in a prechilled mortar and pestle on ice $(\mathrm{w} / \mathrm{v} ; 1: 1)$. The homogenate was centrifuged at $12,000 \mathrm{rpm}$ for $20 \mathrm{~min}$ at $4{ }^{\circ} \mathrm{C}$ and the supernatant served as enzyme source for peroxidase (POX).

\subsubsection{Peroxidase Assay}

POX activities were measured at room temperature according to the standardized procedure of He et al. (2001). The POX assay reaction mixture contained $7.5 \mu \mathrm{L}$ of $10 \mathrm{mM}$ guaiacol in $50 \mathrm{mM}$ sodium phosphate buffer ( $\mathrm{pH} \mathrm{6.0),} 100$ $\mu \mathrm{L}$ of crude extract, $792.5 \mu \mathrm{L}$ of 10 mMsodium phosphate buffer (pH 6.0), and $100 \mu \mathrm{L}$ of $600 \mathrm{mM} \mathrm{H} 2 \mathrm{O}_{2}$. The change in optical density at $470 \mathrm{~nm}$ was measured for 1 min using UVVisible spectrophotometer (Hitachi U-2000, Tokyo, Japan). POX activity was calculated as change in absorbance units $\min ^{-1} \mathrm{mg}^{-1}$.

\subsection{Semiquantitative RT-PCR}

Total RNA was isolated from the seedlings of susceptible cv. Golden acre using plant RNeasy kit (Qiagen). The mRNA was purified using mRNA purification kit (Bangalore Genei, Bangalore, India). One-step reverse transcription-PCR (RTPCR) was performed using $M-M u L V$ reverse transcriptase (BangaloreGenei, Bangalore, India) according to the manufacturer's instructions. First strand cDNA was diluted (1: 5) with RNase free water and used as a template for PCR. The RT-PCR primers were designed from the peroxidase unigene obtained from the analysis of EST library using primer3 software version 0.4.0 (Table 1).

Table 1. Primers used for semi-quantitative PCR analysis.

\begin{tabular}{lll}
\hline Gene & Forward Primer & Reverse Primer \\
\hline \multirow{2}{*}{ 18S rRNA } & GCTACGCAGAAGACAG & TGGGCACACGGAAG \\
& TTGAT & GACATAC \\
Peroxidase & ATGGCTGAGGAGTCTC & TCCAGTAGAGTATCC \\
& CTC & TTCTCG \\
\hline
\end{tabular}

The primers were designed from the unigene of peroxidase and $18 \mathrm{~S}$ rRNA obtained from the SSH library using primer3 software.

18S rRNA was used as endogenous control. Semiquantitative RT-PCR was carried out and the PCR cycling parameters consisted of $94^{\circ} \mathrm{C}$ for 2 mins, annealing at $59^{\circ} \mathrm{C}$ and $60^{\circ} \mathrm{C}$ (depending on the primer) for $1 \mathrm{~min}$ and extension at $72^{\circ} \mathrm{C}$ for 2 mins for 22 and 18 cycles respectively. The PCR products were checked on $1 \%$ agarose gel. 


\section{Results}

\subsection{Construction of Subtracted Library}

Cabbage leaf samples were harvested 48 hpi and used to identify differentially expressed genes upon inoculation with P. fluorescens to susceptible cultivar Golden acre. A cDNA subtractive library was constructed wherein $P$. fluorescens inoculated leaf samples acted as the tester and uninoculated leaf samples as driver. The subtraction efficiency was evaluated by expression of the $18 \mathrm{~S}$ rRNA between subtracted and unsubtracted cDNA's. The amount of 18S rRNA decreased significantly after subtraction and could be detected in agarose gel at 28 PCR cycles whereas in the unsubtracted samples 18S rRNA was detected at 18 PCR cycles. This indicated that the subtraction had worked well. Finally 1000 clones were obtained and 155 clones were randomly selected from the library and the insert size was detected by PCR with SSH primer provided in the subtraction kit. The 120 positive clones carrying single exogenous fragment were detected and the length of the inserted fragments ranged from $200 \mathrm{bp}$ to $700 \mathrm{bp}$.

\subsection{Analysis of EST Sequences}

Table 2. Identification of ESTs from the SSH library obatined from the cabbage-susceptible cultivar treated with the P. fluorescens

\begin{tabular}{|c|c|c|}
\hline Clone no. & BLAST/Similarity & Related Accession no \\
\hline \multicolumn{3}{|c|}{ Metabolism and structural proteins } \\
\hline Ga57 & Ribulose phosphate & GQ184377.1 \\
\hline Ga14 & Photosystem I & P06512 \\
\hline Ga74 & Photosystem II & AY185358.2 \\
\hline Ga100 & Sucrose synthase & AA41682 \\
\hline $\mathrm{Ga} 092$ & $\begin{array}{l}\text { 4-hydroxy phenyl } \\
\text { pyruvate }\end{array}$ & AF251665 \\
\hline $\mathrm{Ga} 25$ & $\begin{array}{l}\text { 40S ribosomal } \\
\text { proteins }\end{array}$ & AF144752.1 \\
\hline Ga19 & Membrane proteins & U13631.1 \\
\hline Ga09 & $\begin{array}{l}\text { 60S Ribosomal } \\
\text { proteins }\end{array}$ & L21897.1 \\
\hline \multicolumn{3}{|c|}{ Defense related } \\
\hline Ga99 & $\begin{array}{l}\text { WRKY transcription } \\
\text { factor }\end{array}$ & GQ168839.1 \\
\hline Ga64 & Super oxide dismutase & AF071112.1 \\
\hline Ga62 & Cytochrome P450 & AY029178.1 \\
\hline Ga19 & Heat shock proteins & AAB97316.1 \\
\hline $\mathrm{Ga} 4$ & $\begin{array}{l}\text { Glutathione } \\
\text { Peroxidase }\end{array}$ & AF411209.1 \\
\hline Ga 1 & Beta glucosidase & NP199277 \\
\hline Ga 99 & $\begin{array}{l}\text { MAP- kinase like } \\
\text { protein }\end{array}$ & AAX96170 \\
\hline Ga 50 & Peroxidase & GR723799.1 \\
\hline \multicolumn{3}{|c|}{ Signalling proteins } \\
\hline Ga 3 & $\begin{array}{l}\text { Pyruvate } \\
\text { dehydrogenase }\end{array}$ & JF682847.1 \\
\hline Ga 7 & Phosphatase & FJ346565.1 \\
\hline Ga 5 & Zinc finger protein & HM579881.1 \\
\hline Ga 24 & $\begin{array}{l}\mathrm{ABC} \text { transporter like } \\
\text { protein }\end{array}$ & DQ296184.1 \\
\hline Ga 45 & $\begin{array}{l}\text { Serine/threonine } \\
\text { kinase gene }\end{array}$ & DQ375116 \\
\hline
\end{tabular}

The ESTs obtained from SSH library were subjected to BLAST analysis and the functions were assigned based on homology.

The 120 unigenes obtained were classified into three major categories: Metabolism and structural proteins, Defense related, and Signalling pathway related. The metabolism related unigenes accounted for $32 \%$, defense related (42\%), Signalling pathway related (26\%) (Fig. 1).

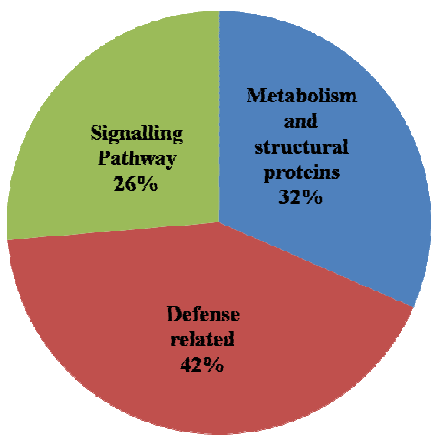

Fig 1. Classification of ESTs obtained from the SSH library of the susceptible cultivar and assignment of putative biological functions based on homologies to sequences of known function identified by BLAST N analysis.

All the unigenes were subjected to similarity search using BLASTX, BLASTN dbEST databases. Sequences showing the E-value $<10^{-3}$ were considered as significant. The most abundant group consisted of the defense related genes peroxidase, HSP70, superoxide dismutase were prominent which are predicted to play an important role in the resistance process upon pathogen attack followed by the metabolism and structural proteins category (Table 2).

Some of the unigenes like Jasmonate O-methyltransferase (Ga8), S-adenosylmethionine (Ga89), novel protein (Ga33) were found. The unigene Ga33 upon analysis was found to belong to SWEET class of protein. 10 unigenes have been submitted to dbEST with the accession numbers JZ585524 to JZ585533 (Table 3).

Table 3. List of upregulated ESTs from the cabbage-susceptible cultivar after treatment with the P. fluorescens

\begin{tabular}{lll}
\hline Clone No & dbEST id & Putative id \\
\hline Ga10 & JZ585524 & Transcription factor \\
Ga8 & JZ585525 & Jasmonate O-methyltransferase \\
Ga89 & JZ585526 & S-adenosylmethionine \\
Ga5 & JZ585527 & Thionin \\
Ga21 & JZ585528 & Glutathione-S-transferase \\
Ga33 & JZ585529 & Novel protein (SWEET Protein) \\
Ga91 & JZ585530 & Histone \\
Ga122 & JZ585531 & Lipase \\
Ga1 & JZ585532 & Disease Resistance Protein \\
Ga6 & JZ585533 & Disease Resistance Protein \\
\hline
\end{tabular}

The ESTs obtained from the SSH library have been submitted to dbEST database 
Since the peroxidase was very prominent in the study, the peroxidase assay was performed followed by the transcript accumulation study by semiquantitative RT-PCR.

\subsection{Semiquantitative RT-PCR}

The defense related unigene, peroxidase, showed high homology percentage and were selected to study their expression in resistant and susceptible cultivars during infection with Xanthomonas campestris pv. campestris. The transcript level was investigated at 48hpi. The genes were compared with the internal control being $18 \mathrm{~S}$ rRNA. The $18 \mathrm{~S}$ rRNA expressed in both cultivars. The expression of $18 \mathrm{~S}$ rRNA was constitutively expressed as compared to peroxidase. The susceptible cultivar showed that upon treatment with $P$. fluorescens showed higher transcript accumulation showing which is evident in the enzyme assay (Fig 2).

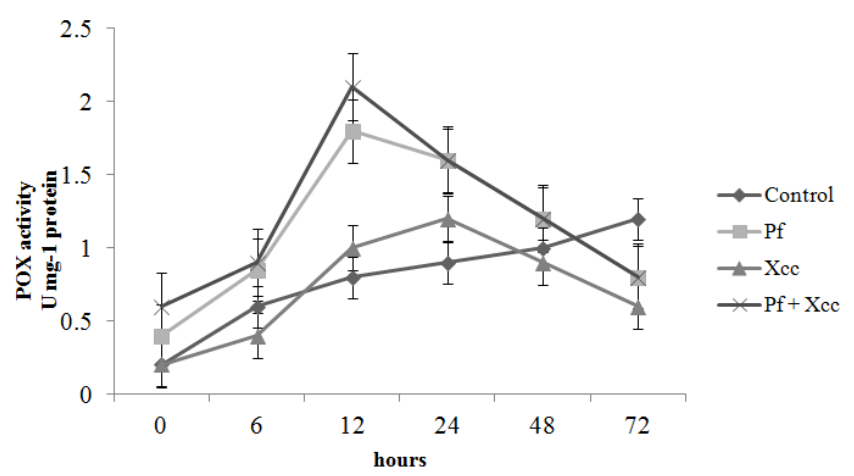

Fig 2. Peroxidase activity of the susceptible cultivar. $P f+X c c-P$. fluorescens pre-treated cabbage seelings challenge inoculated with $X$. campestris $p v$. campestris; Xcc-cabbage seedlings inoculated with $X$. campestris $p v$. campestris; Pf - seedlings treated with P. fluorescens; $C$ - control seedlings treated with distilled water. The means of three independent experiments, bars indicate $S E$.

The resistant cultivar at 48 hpi showed better transcript accumulation upon challenge inoculation of the pretreated cabbage seedlings compared to the susceptible cultivar (Fig. 3).

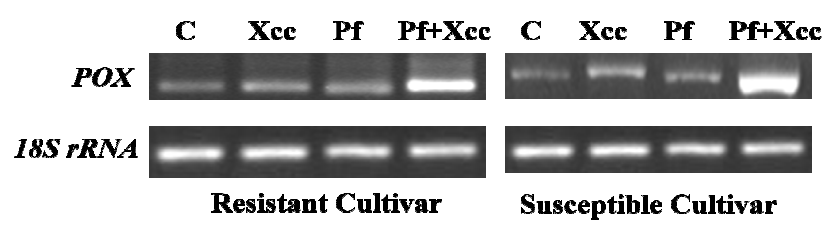

Fig 3. Comparison of induced gene expression pattern of peroxidase gene and $18 S$ rRNA in cabbage cultivars. Resistant cultivar - Pusa mukta. $P f+X c c-P$. fluorescens pre-treated seeds challenge inoculated with $X$. campestris $p v$. campestris; Xcc - seeds inoculated with X. campestris $p v$. campestris; Pf - seeds treated with P. fluorescens; $C$ - control seeds treated with distilled water.

\section{Discussion}

The phyllosphere represents a niche with great agricultural and environmental significance. The significant interactions of phyllosphere microbial inhabitants affect the fitness of natural plant populations, quality and productivity of agricultural crops. Phyllosphere bacteria can promote plant growth and both suppress the colonisation of infection of tissues by plant pathogens (Lindow and Brandl 2003).

The surfactants released by some of the epiphytic pseudomonads increase the wettability of leaf surfaces making it easier for microorganisms to use water and increasing solubilisation and diffusion of nutrients, thereby increasing substrate availability to epiphytic bacteria. The increased permeability of the cuticle enhancing water and nutrient availability in the phyllosphere have been shown by some bacteria colonizing the phyllosphere. (Hutchison et al. 1995).Bacteria multiplying inside the intercellular spaces of tissues can hardly be reached with chemicals or antibacterial substances, which have been used until now and caused hazard to human beings, animals, plants and the environment. When the disease occurs in clusters, overcoming it is in most cases unsuccessful. Therefore, we must not depend entirely on defensive elements but preventive measures should be taken first so that the pathogen can be kept far from the plant either by quarantine regulations or using healthy seeds. A considerable advantage of using antibiotics as opposed to other plant protective agents is that they have a real absorbing ability, and they translocate in tissues, which are considered significant with bacterial diseases.Bacteria being the most abundant inhabitants of the phyllosphere have received attention on the interactions occuring between bacteria on the leaves.. Studies of the composition of bacterial communities on leaves have been numerous but rather limited in scope. The phyllosphere is both scientifically and economically a critical habitat to study microbial ecology. Because of the importance of many phyllosphere microbial inhabitants to plant health, there will likely be many practical applications that result from a better understanding of the interactions of microbes with plants and among themselves. Thus, knowledge of phyllosphere offers to the field of microbial ecology that contribute to more efficient and less environmentally damaging means of plant protection. Lindow and Brandl (2003) suggested that presence of a functional type III secretion pathway in Pseudomonas fluorescens provides the capacity to modify the local habitat needed for growth and survival in the phyllosphere.

In the present study, majority of genes identified in the subtractive analyses were pathogen, disease or stressrelated. For instance, S-adenosylmethionine (Ga89) has been shown to be involved in stress responses (Chen et al. 2010). Some of the other genes found in our study have been reported to encode pathogenesis related (PR) proteins. The DNA-binding protein WRKY reportedly plays an important role in defense responses to pathogens. The study suggests that a significant amount of genes have overlapping functions in both pathogen responses. Besides the well-characterized proteins with a function in plant defence, more recently, a few additional ones have been described. Amongst these are phospholipid-derived molecules with a function as novel, second messengers in 
signal transduction pathways for plant defence. The SWEET family of plant transmembrane proteins was a significant finding of the present study. SWEET proteins were shown to transport glucose and sucrose across cell membranes, thus contributing to phloem unloading (Chen et al. 2010). A subset of SWEET genes in Arabidopsis and rice are transcriptionally induced during bacterial and fungal infection (Chen et al. 2010). The importance of these sugar transporters for disease susceptibility has been revealed in rice. The occurrence of the SWEET protein which is a transmembrane protein probably helps in inducing the interaction of the host phyllosphere upon application of $P$. fluorescens.In summary, application of the non-pathogenic bacterium $P$. fluorescens to the phyllosphere of cabbage cv. Golden acre leads to the up-regulation of a large number of transcripts. Several of these transcripts encode proteins/enzymes that are also implicated during infection with the pathogen black rot pathogen. Thus, it can be concluded that the expression of these proteins, initiated by the non-pathogenic bacterium, perhaps helps to cope against infection with a pathogen. The molecular mechanism of signal perception of $P$. fluorescens by the host plant is still elusive. A possible candidate for an elicitor of the plant defence reaction could be flagellin that is released by $P$. fluorescens (Singh et al. 2004) and which is well known as a signal molecule (Zipfel et al. 2004)

In the very early stages of the plant defence, reactive oxygen species (ROS) are formed to prevent or inhibit pathogen infection. This oxidative burst requires a plasma membrane-located NADPH oxidoreductase that generates hydrogen peroxide, which can destroy the infected tissue and avoids the spreading and multiplication of pathogens. On the other hand, it is important that the uninfected tissues are protected from damage by ROS. Therefore, it is not surprising that the results of the experiments undertaken reveal that a substantial number of transcripts that encode enzymes or proteins, which have a role in the adaptation process to oxidative or more general stress, are up-regulated after the application of the non-pathogenic bacterium to keep the fungus under control. It is clear from the present studies that the defense-related enzymes are up-regulated. Hence, the regulated levels of defense-related enzymes can be effectively used to screen for host resistance.

POX is a key enzyme in the biosynthesis of lignin. Increased activity of cell wall bound peroxidases have been elicited in different plants due to pathogen infection. In our study, POX activity increased. Increased activity of POX has been elicited by $P$. fluorescens in various plants such as rice (Nandakumar et al. 2001), tomato (Ramamoorthy et al. 2002) and mulberry (Ganeshmoorthi et al. 2008). In conclusion, the present study proved that $\mathrm{P}$. fluorescens induced resistance against $X$. campestris pv. campestris in cabbage seedlings is associated with the enhanced expression of genes for defense-related protein. The significant finding of the study was the identification of the SWEET protein unigene in cabbage upon interaction with $P$. fluorescens.

\section{Acknowledgements}

RKR acknowledges Council of Scientific and Industrial Research (CSIR), New Delhi, India for financial support in the form of Senior Research Fellowship [9/119(0814)2K10EMRI dated 8.3.2010)]. The authors do not have any conflict of interest.

\section{References}

[1] Alstrom S. (1991) Induction of disease resistance in common bean susceptible to halo blight pathogen after seed bacterization with rhizosphere pseudomonads. J Gen Appl Microbiol 37: 495-501.

[2] Beattie GA, Lindow SE. (1995) The secret life of foliar bacterial pathogens on leaves. Ann Rev of Phytopathol $33: 145-172$.

[3] Burr TJ, Matteson MC, Smith CA, Corral-Gracia MR,Huang TC. (1996) Effectiveness of bacteria and yeasts from apple orchards as biological control agents of apple scab. Biol Control 6:151-157.

[4] Chen LQ, Hou BH, Lalonde S, Takanaga H, Hartung ML, Qu XQ, Guo WJ, Kim JG, Underwood W, Chaudhuri B, Chermak D, Antony G, White FF, Somerville SC, Mudgett MB, Frommer WB. (2010) Sugar transporters for intercellular exchange and nutrition of pathogens. Nature 468:527-532.

[5] Das KK, Panda D, Nagaraju M, Sharma SG, Sarkar RK. (2004) Antioxidant enzymes and aldehyde releasing capacity of rice cultivars (Oryzae sativa L.) and determinants of anaerobic seedling establishment capacity. Bulg J Plant Physiol 30:34-44.

[6] Diatchenko L, Lukyanov S, Lau YF, Siebert PD. (1999) Suppression subtractive hybridisation: a versatile method for identifying differentially expressed genes. Methods in Enzymol 303:349-380.

[7] Ganeshmoorthi P, Anand T, Prakasan V, Bharani M, Ragupathi N, Samiyappan R. (2008) Plant growth promoting rhizobacterial (PGPR) bioconsortia mediates induction of defense-related proteins against infection of root rot pathogen in mulberry plants. J Plant Interact 3:233-244.

[8] He CY, Hsiang T, Wolyn DJ. (2001) Activation of defense response to Fusarium infection in Asparagus densiflorus. Eur J Plant Pathol 107:473-483.

[9] Hoffland E, Hakulinen J, Van Pelt JA. (1996) Comparison of systemic resistance induced by avirulent and nonpathogenic Pseudomonas species. Phytopathol 86:757-762.

[10] International Seed Testing Authority. (2014) Detection of Xanthomonas campestris pv. campestris on Brassica spp. disinfested/disinfected seed with grinding.

[11] Hutchison ML, Tester MA, and Gross DC. (1995) Role of biosurfactant and ion channel18 forming activities of syringomycin in transmembrane ion flux: a model for the mechanism of action in the plant pathogen interaction. Molec Plant-Microb Interac 8:610-620.

[12] King EO, Ward MK, RaneyDE. (1956) Two simple media for the demonstration of pyocyanin and fluorescein. J Laboratory Clin Med 4:301-307. 
[13] Kurkcuoglu S, Degenhardt J, Lensing J, Abdul Nasser AlMasri, Gau AE. (2007) Identification of differentially expressed genes in Malus domestica after application of the non-pathogenic bacterium Pseudomonas fluorescens Bk3 to the phyllosphere. $J$ Experimental Botany 58:733-741

[14] Lindow SE, Brandl MT. (2003) Microbiology of the phyllosphere. Appl Environ Microbiol 69:1875-1883.

[15] Madamanchi NR and Alscher RG. (1991) Metabolic bases for differences in sensitivity of two pea cultivars to sulfur dioxide. Plant Physiol 97:88-93.

[16] Massomo SMS, Mortensen CN, Mabagala RB, Newman MA, Hockenhull J. (2004) Biological control of Black Rot (Xanthomonas campestris pv campestris) of Cabbage in Tanzania with Bacillus strains. J Phytopathol 152:98-105.

[17] Meena, B, Radhajeyalakshmi R, Marimuthu T, Vidhyasekaran P, Doraisamy S, Velazhahan R.(2000) Induction of pathogenesis related proteins, phenolics and phenylalanine ammonia lyase in groundnut by Pseudomonas fluorescens. J. Plant Dis. Protect 107:514 - 527.

[18] Nandakumar R, Babu S, Viswanathan R, Raguchander T, Samiyappan R. (2001) Induction of systemic resistance in rice against sheath blight disease by Pseudomonas fluorescens. Soil Biol Biochem 33:603-612.

[19] Ramamoorthy V, Raguchander T, Samiyappan R. (2002) Induction of defense-related proteins in tomato roots treated with Pseudomonas fluorescens Pf1 and Fusarium oxysporum f. sp. lycopersici. Plant Soil 239:55-68.

[20] Schmidt C, Lorenz D, Wolf G (2001) Biological control of the grapevine dieback fungus Eutypa lata. Screening of bacterial antagonists. J Phytopathol 149:427-435.

[21] Shruti Mishra, Naveen K Arora. (2012). Evaluation of rhizospheric Pseudomonas and Bacillus as biocontrol tool for Xanthomonas campestris pv campestris. World J Microbiol Biotechnol, 28:693-702.

[22] Singh P, Piotrowski M, Kloppstech K, Gau AE (2004). Investigations on epiphytic living Pseudomonas species from Malus domestica with an antagonistic effect to Venturia inaequalis on isolated plant cuticle membranes. Environ Microbiol 11:1149-1158.

[23] Staub T, Williams PH (1972) Factors influencing black rot lesion development in resistant and susceptible cabbage. Phytopathol 62:722-728.

[24] Vanitha SC, Niranjana SR, Mortensen CN, Umesha S (2009) Bacterial wilt of tomato in Karnataka and its management by Pseudomonas fluorescens. Biocontrol 54:685-695

[25] Wei G, Kloepper JW, Tuzun S. (1991) Induction of systemic resistance in cucumber to Colletotrichum orbiculare by selected strains of plant growth promoting rhizobacteria. Phytopathol 81:1508-1517.

[26] Williams PH, Staub T, Sutton JC. (1972) Inheritance of black rot resistance in cabbage. Phytopathol 62:247-252

[27] Williams PH. 1980. Black rot: a continuing threat to world crucifers. Plant Dis 64:736-742.

[28] Zipfel C, Robatzek S, Navarro L, Oakeley EJ, Jones JDG, Felix G, Boller T. (2004). Bacterial disease resistance in Arabidopsis through flagellin perception. Nature 428:764-767. 